\title{
Dewan Pembina
}

Dr. Ir. M. Yusuf S. Barusman, M.B.A

Dr. Andala Rama Putra Barusman, S.E., M.A.Ec.

\section{Penanggung Jawab}

Dra. Rosmiaty Tarmizi, M.M.Akt. C.A

\section{Pimpinan Redaksi}

Dr. Angrita Denziana, S.E., M.M, Ak. C.A

\author{
Sekretaris Redaksi \\ Riswan, S.E., M.S.Ak \\ Haninun, S.E., M.S.Ak
}

\section{Penyuting Ahli}

Tina Miniawati, S.E., M.B.A. (Universitas Trisakti)

Dr. Khomsiyah, S.E., M.M. (Universitas Trisakti)

Dr. Lindrianasari, S.E., M.Si.Akt., C.A. (Universitas Lampung)

Sujoko Efferin, Mcom (Hons), MA(Econ), Ph.D. (Universitas Surabaya)

\section{Penerbit}

Universitas Bandar Lampung

Fakultas Ekonomi dan Bisnis Program Studi Akuntansi

SENARAI-Jurnal Akuntansi \& Keuangan Terbit 2 kali setahun pada bulan Maret \&

September

Artikel yang dimuat berupa hasil riset Empiris dan telaah teoritis konsepsual yang kritis dalam kajian bidang akuntansi, auditing, perpajakan, dan keuangan.

\section{Alamat Redaksi}

Gedung G- Program Studi Akuntansi Fakultas Ekonomi dan Bisnis Universitas Bandar Lampung

Kampus A Jalan Z.A Pagar Alam No. 26 Labuan Ratu Bandar Lampung 35142

Telp: (0721) 701979, Fax: (0721) 701467, Email: Prodi.akuntansi@ubl.ac.id 


\section{JURNAL \\ AIKUNTANSI \& KEUANGAN}

Volume 7, No. 2, September 2016

ISSN: 2087-2054

Pengaruh Transparansi Dan Akuntabilitas Laporan Keuangan Pemerintah Daerah (LKPD) Terhadap Tingkat Korupsi Pemerintah Daerah (Studi Pada Pemerintah Kota Se-Sumatera)

\section{Khairudin \& Rina Erlanda}

Pengaruh Tingkat Pertumbuhan Penjualan Dan Perputaran Piutang Terhadap Likuiditas Perusahaan Pada Perusahaan Manufaktur Yang Terdaftar Di Bursa Efek Indonesia Periode 2012-2014

\section{Indrayenti \& Siska Natania}

Analisis Tingkat Kesehatan Koperasi Pada Koperasi Simpan Pinjam Di Kabupaten Tulang Bawang Barat

\section{Herry Goenawan Soedarsa \& Desty Natalia}

Analisis Faktor-Faktor Yang Mempengaruhi Pemilihan Metode Penilaian Persediaan Pada Perusahaan Dagang Yang Terdaftar Di Bursa Efek Indonesia Periode 2010-2014

\section{Riswan \& Restiani Fasa}

Analisis Du Pont System Dalam Mengukur Kinerja Keuangan Perusahaan (Studi Kasus Pada Perusahaan Telekomunikasi Yang Terdaftar

Di Bursa Efek Indonesia Periode 2012-2014)

\section{Rosmiati Tarmizi \& Merlinda Marlim}

Analisis Simulasi Penerapan Akuntansi Sumber Daya Manusia Terhadap Perbandingan Kinerja Keuangan (Studi Kasus Pada Pt Bank Pembangunan Daerah Lampung Tahun 2012-2014)

\section{Yunus Fiscal \& Desma}

Analisis Ukuran Perusahaan Dan Profitabilitas Terhadap Nilai Perusahaan (Studi Empiris Pada Perusahaan Yang Tergolong Lq45 Di Bei Periode 2011-2014) Angrita Denziana \&Winda Monica

Pengaruh Brand Image, Dan Lapangan Pekerjaan Terhadap Keputusan Mahasiswa Untuk Memilih Jurusan Akuntansi Pada Perguruan Tinggi Yang Ada Di Bandar Lampung

\section{Chairul Anwar \& Fredi Budiman}




\section{JURNAL}

AKUNTANSI \& KEUANGAN

Volume 7, No. 2, September 2016

ISSN: 2087-2054

Daftar Isi

Halaman

Pengaruh Transparansi Dan Akuntabilitas Laporan Keuangan Pemerintah Daerah

(LKPD) Terhadap Tingkat Korupsi Pemerintah Daerah (Studi Pada Pemerintah

Kota Se-Sumatera)

Khairudin \& Rina Erlanda

Pengaruh Tingkat Pertumbuhan Penjualan Dan Perputaran Piutang Terhadap

$155-167$

Likuiditas Perusahaan Pada Perusahaan Manufaktur Yang Terdaftar Di Bursa

Efek Indonesia Periode 2012-2014

Indrayenti \& Siska Natania

Analisis Tingkat Kesehatan Koperasi Pada Koperasi Simpan Pinjam Di

Kabupaten Tulang Bawang Barat

Herry Goenawan Soedarsa \& Desty Natalia

Analisis Faktor-Faktor Yang Mempengaruhi Pemilihan Metode Penilaian

Persediaan Pada Perusahaan Dagang Yang Terdaftar Di Bursa Efek Indonesia

Periode 2010-2014

Riswan \& Restiani Fasa

Analisis Du Pont System Dalam Mengukur Kinerja Keuangan Perusahaan

(Studi Kasus Pada Perusahaan Telekomunikasi Yang Terdaftar

Di Bursa Efek Indonesia Periode 2012-2014)

Rosmiati Tarmizi \& Merlinda Marlim

Analisis Simulasi Penerapan Akuntansi Sumber Daya Manusia Terhadap

Perbandingan Kinerja Keuangan (Studi Kasus Pada Pt Bank Pembangunan

Daerah Lampung Tahun 2012-2014)

Yunus Fiscal \& Desma

Analisis Ukuran Perusahaan Dan Profitabilitas Terhadap Nilai Perusahaan (Studi Empiris Pada Perusahaan Yang Tergolong Lq45 Di Bei Periode 20112014)

Angrita Denziana \&Winda Monica

Pengaruh Brand Image, Dan Lapangan Pekerjaan Terhadap Keputusan

Mahasiswa Untuk Memilih Jurusan Akuntansi Pada Perguruan Tinggi Yang

Ada Di Bandar Lampung

Chairul Anwar \& Fredi Budiman 


\section{JURNAL \\ AKUNTANSI \& KEUANGAN}

Volume 7, No. 2, September 2016

ISSN: $2087-2054$

\section{Informasi Kebijakan dan Selingkung Berkala}

\section{Kebijakan editorial}

JURNAL Akuntansi \& Keuangan adalah sebuah berkala yang dipublikasikan oleh Universitas Bandar Lampung, yang bertujuan untuk menjadi wadah kreatifitas para akademisi, profesional, peneliti, dan mahasiswa di bidang Akuntansi dan Keuangan termasuk juga bidang Auditing, Sistem Informasi Akuntansi, Tata kelola Perusahaan, Perpajakan, Akuntansi Internasional, Akuntansi Managemen, Akuntansi Keperilakuaan, Pasar Modal dan lain sebagainya. Topik yang semakin meluas di bidang kajian riset Akuntansi diakomodir publikasinya di dalam berkala ini.

Paper yang akan dipublikasikan di dalam berkala JURNAL Akuntansi \& Keuangan harus ditulis di dalam bahasa Indonesia yang baik dan sesuai dengan EYD. Semua instrumen yang digunakan untuk memperoleh data penelitian harus dimasukkan di dalam lampiran paper penelitian, paling tidak, penulis bersedia memberikan klarifikasi atas instrumen yang digunakan saat ada permintaan dari peneliti lainnya.

\section{Sekretariat Editor Berkala}

Gedung F - Fakultas Ekonomi Universitas Bandar Lampung

Fakultas Ekonomi Program Studi Akuntansi

Kampus A Jalan Z.A. Pagar Alam No. 26 Labuhan Ratu Bandar Lampung 35142 Telp.: (0721) 701979, Fax.: (0721) 701467, Email:

\section{Petunjuk penulisan}

Artikel yang dikirim ke JURNAL Akuntansi \& Keuangan harus mengikuti petunjuk seperti berikut:

1. Naskah merupakan naskah asli yang belum pernah diterbitkan atau sedang dilakukan penilaian pada berkala lain. Naskah ditulis dalam bahasa Indonesia dengan jarak 1 spasi, sepanjang 20-30 halaman kertas A4 dengan tipe huruf Times New Roman.. Naskah dikirim atau diserahkan ke sekretariat JURNAL Akuntansi \& Keuangan rangkap satu disertai disket berikut dengan biodata penulis dan alamat lengkap (kantor dan rumah) pada lembaran yang terpisah dari halaman pertama artikel.

2. Judul naskah dapat ditulis dengan menggambarkan isi pokok tulisan, dan atau ditulis secara ringkas, jelas, dan menarik.

3. Nama Penulis disertai catatan kaki tentang profesi dan lembaga tempat penulis bekerja dalam naskah yang telah diterima untuk diterbutkan.

4. Abstrak ketik satu spasi, tidak lebih dari 250 kata dalam bahasa Inggris. Abstrak memuat tujuan penelitian, isu, permasalahan, sampel dan metode penelitian, serta hasil dan simpulan (jika memungkinan). 
5. Pendahuluan beriksikan uraian tentang latar belakang masalah, ruang lingkup penelitian, dan telaah pustaka yang terkait dengan permasalahan yang dikaji, serta rumusan hipotesis (jika ada). Uraian pendahuluan maksimum $10 \%$ total halaman.

6. Untuk penelitian kuantitatif,

a. Telaah Literatur dan Pengembangan Hipotesis memuat paling tidak satu buah teori yang menjadi dasar pemikiran penelitian. Hipotesis dikembangkan menggunakan asumsi dasar teori dan hasil penelitian sebelumnya. Telah literatur maksimum $40 \%$ total halaman.

b. Metodologi Penelitian meliputi uraian yang rinci tentang bahan yang digunakan, metoda yang dipilih, teknik, dan cakupan penelitian. Uraian bahan dan metoda maksimum $20 \%$ total halaman.

7. Untuk penelitian kualitatif menyesuaikan dengan metodologi kualitatif.

8. Hasil dan Pembahasan merupakan uraian obyektif dari-hasil penelitian dan pembahasan dilakukan untuk memperkaya makna hasil penelitian. Uraian hasil dan pembahasan minimum $25 \%$ total halaman.

9. Simpulan yang merupakan rumusan dari hasil-hasil penelitian. Harus ada sajian dalam satu kalimat inti yang menjadi simpulan utama. Simpulan maksimum 10\% dari keseluruhan lembar artikel.

10. Referensi (Daftar Pustaka) ditulis berurutan berdasarkan alphabetical, disusun menggunakan suku kata terakhir dari nama penulisnya, atau institusi jika dikeluarkan oleh organisasi.

a. Buku: nama penulis, tahun penerbitan, judul lengkap buku, penyunting (jika ada), nama penerbit, dan kota penerbitan.

b. Artikel dalam buku: nama penulis, tahun penerbitan, judul artikel/tulisan, judul buku, nama penyunting, kota penerbitan, nama penerbit, dan halaman.

c. Terbitan berkala: nama penulis, tahun penerbitan, judul tulisan, judul terbitan (bila disingkat, sebaiknya menggunakan singkatan yang baku), volume, nomor, dan halaman.

d. Artikel dalam internet: nama penulis, judul, dan situsnya.

e. Tabel diberi nomor dan judul dilengkapi dengan sumber data yang ditulis dibawah badan tabel, diikuti tempat dan waktu pengambilan data.

f. Ilustrasi dapat berupa gambar, grafik, diagram, peta, dan foto diberi nomor dan judul.

11. Setiap referensi yang digunakan di dalam naskah artikel menggunakan petunjuk yang dirujuk pada The Indonesian Journal of Accounting Research, sebagai berikut:

A. Kutipan dalam tubuh naskah paper harus disesuaikan dengan contoh berikut:

I. Satu sumber kutipan dengan satu penulis (Brownell, 1981).

II. Satu sumber kutipan dengan dua penulis (Frucot dan Shearon, 1991).

III. Satu sumber kutipan dengan lebih dari satu penulis (Hotstede et al., 1990).

IV. Dua sumber kutipan dengan penulis yang berbeda (Dunk, 1990; Mia, 1988).

V. Dua sumber kutipan dengan satu penulis (Brownell, 1981, 1983).

VI. Dua sumber kutipan dengan satu penulis diterbitkan pada tahun yang sama (Brownell, 1982a, 1982b).

VII. Sumber kutipan dari lembaga harus dinyatakan dengan menggunakan akronim institusi (FASB, 1994)

B. Setiap artikel harus menulis referensi menggunakan panduan berikut:

I. Referensi harus tercantum dalam urutan abjad dari nama belakang penulis atau nama lembaga. 
II. Referensi harus dinyatakan dengan urutan sebagai berikut: penulis (s) nama, tahun publikasi, judul kertas atau buku teks, nama jurnal atau penerbit dan nomor halaman. Contoh:

a) Amerika Akuntansi Association, Komite Konsep dan Standar Laporan Keuangan Eksternal. 1977. Pernyataan tentang Teori Akuntansi dan Teori Penerimaan. Sarasota, FL: AAA.

b) Demski, J. S., dan D. E. M. Sappington. 1989. Struktur hirarkis dan akuntansi pertanggungjawaban, Jurnal Akuntansi Penelitian 27 (Spring): 40-58.

c) Dye, R. B., dan R. Magee. 1989. Biaya Kontijensi untuk perusahaan audit. Kertas kerja, Northwestern University, Evansto, IL.

d) Indriantoro, N. 1993. Pengaruh Penganggaran Partisipatif Terhadap Prestasi Kerja dan Kepuasan Kerja dengan Locus of Control dan Dimensi Budaya sebagai Moderating Variabel. Ph.D. Disertasi. University of Kentucky, Lexington.

e) Naim, A. 1997. Analisis Penggunaan Akuntansi Biaya Produk Dalam Keputusan Harga oligopolistik. Jurnal Ekonomi Dan Bisnis Indonesia 12 (3): 43-50.

f) Porcano, T. M. 1984a. Keadilan distributif dan Kebijakan Pajak. Akuntansi Ulasan 59 (4): 619-636.

g) -------. 1984b. Pengaruh Persepsi Kebijakan Pajak Niat Investasi Perusahaan. The Journal of American Association Perpajakan 6 (Fall): 719.

h) Pyndyk, R. S. dan D. L. Rubinfield. 1987. Model ekonometrik \& Forecasts Ekonomi, 3rd ed. NY: McGraw-Hill Publishing, Inc.

12. Author(s) harus melampirkan CV, alamat email, alamat korespondensi dan pernyataan yang menyatakan pasal tersebut tidak sedang disampaikan kepada atau diterbitkan oleh jurnal lain dalam email tersebut dan /atau pos. 


\title{
ANALISIS DU PONT SYSTEM DALAM MENGUKUR KINERJA KEUANGAN PERUSAHAAN (STUDI KASUS PADA PERUSAHAAN TELEKOMUNIKASI YANG TERDAFTAR DI BURSA EFEK INDONESIA PERIODE 2012-2014)
}

\author{
Rosmiati Tarmizi \\ Merlinda Marlim \\ (Universitas Bandar Lampung) \\ E-Mail: rosmiati@ubl.ac.id
}

\begin{abstract}
The purpose of this study is for analyzing the financial performance use the analysis Du Pont System in Telecommunication Company listed on the Indonesia Stock Exchange. Du Pont Systemanalysis is an analysis provides information on the factors that led to the rise and fall the company financial performance shows the relationship between Net Profit Margin, Total Assets Turnover and Return on Investment to determine the Return on Equity of the company. This research uses descriptive research. The data used is secondary data. Data collection methods used in this research is the method of documentation or literature study. The analysis technique used is descriptive qualitative analysis. Based on the results of this study concluded that financial performance of the Telecommunication Company listed on the Indonesia Stock Exchange 2012-2014 period is that the financial performance is generally not good because as the value of Return on Investment and Return on Equity is negative and even below the industry standard, except PT. Telekomunikasi Indonesia, Tbk financial performance is quite good for the value of Return on Investment and Return on Equity positive, although below the industry standard. Therefore, the company must improve the performance of the company, in order to achieve the company's financial performance above industry standards.
\end{abstract}

Keywords: Financial Ratios, DuPontSystemAnalysis, Financial Performace

\section{Latar Belakang}

Pada tahun 1984 Teknologi pertama kali diperkenalkan di Indonesia, seiring dengan perkembangan teknologi, pada tahun 1994 muncullah operator pertama GSM di Indonesia yaitu PT. Satelit Palapa Indonesia (Satelindo) atau sekarang bernama PT.Indosat, Tbk. Lalu pada tahun 1995 muncul operator GSM kedua yaitu Telkomsel. Dengan munculnya 2 operator GSM di Indonesia maka lahir Undang-Undang No.36 Tahun 1999 tentang Telekomunikasi. Dari munculnya undang-undang tersebut maka perkembangan teknologi di Indonesia semakin berkembang dengan munculnya perusahaan sejenis yang akan menjadi pesaing baru.

Setiap perusahaan harus mampu menjalankan kinerja perusahaan dengan baik untuk bertahan dalam persaingan yang kompetitif. Untuk itu informasi posisi keuangan dan kinerja keuangan di masa lalu sering digunakan sebagai dasar untuk memprediksi posisi keuangan dimasa depan, karena terdapat 6 perusahaan yang sejenis mengakibatkan kebimbangan 
investor untuk menanamkan modalnya, oleh sebab itu agar prediksi yang dilakukan dalam penerapan pengambilan keputusan dalam mencari investor atau kepercayaan investor atas kinerja keuangan sangatlah penting untuk usaha perusahaan dalam penjualan sahamnya, maka perlu dilakukan sebuah analisis kinerja keuangan perusahaan salah satunya dengan menggunakan alat analisis du pont system.

Analisis du pont system dapat mengukur kinerja keuangan secara lebih terperinci yaitu menunjukkan bagaimana margin laba bersih, perputaran total aset dan equity multiplier dalam menentukan tingkat pengembalian ekuitas. Melalui analisis $d u$ pont system ini memberikan informasi mengenai berbagai faktor yang menyebabkan naik turunnya kinerja keuangan sebuah perusahaan, sebenarnya metode hampir sama dengan analisis laporan keuangan biasa, namun pendekatannya lebih integrative dengan menggunakan komposisi laporan keuangan sebagai elemen analisisnya, yaitu dengan menganalisis rasio keuangan agar perusahaan dapat mengetahui berbagai faktor yang mempengaruhi efektivitasnya dalam mengelola sumber daya yang perusahaan miliki, sehingga perencanaan keuangannya akan lebih baik dimasa yang akan datang.

Tujuan analisis ini digunakan untuk mengetahui sejauh mana efektivitas perusahaan dalam mengelola asetnya dari penjualan yang menghasilkan laba, sehingga analisis ini mencakup berbagai rasio. Du Pont System ini menggabungkan rasio aktivitas/perputaran aset dengan rasio profitabilitas/ labaMenurut Fraser dan Ormiston yang diterjemahkan oleh (Setyautama, 2004) rasio profitabilitas menunjukkan efisiensi dan kinerja keseluruhan. Jenis rasio profitabilitas meliputi: Net Profit Margin, Return on Investment, \&Return on Equity, sedangkan rasio aktivitas yang digunakan adalah Total Assets Turnoverkarena mengukur sejauh mana efektivitas perusahaan dalam mengelola keseluruhan total asetnya.

Net Profit Margindipengaruhi oleh tingkat penjualan dan laba bersih yang dihasilkan. Berarti Net Profit Marginini mencakup pula seluruh biaya yang digunakan dalam operasional perusahaan. Rasio aktivitas dipengaruhi oleh penjualan dan total aset. Sedangkan Return on Equity dipengaruhi oleh Equity Multiplier dan Return on Investment, Equity Multiplier yaitu kemampuan perusahaan dalam mendayagunakan total ekuitas.

Rasio ini juga diartikan sebagai berapa porsi dari aset perusahaan dibiayai oleh pemegang saham. Semakin kecil rasio ini, berarti porsi pemegang saham akan semakin besar, sehingga kinerjanya akan semakin baik karena persentase untuk pembayaran bunga semakin kecil dan Return on Investment yaitu kemampuan perusahaan dalam menghasilkan laba bersih setelah pajak dari aset yang dipergunakan untuk penjualan. Sehingga Return on Equity 
digunakan untuk mengukur besarnya tingkat pengembalian modal dari perusahaan. Dapat dikatakan bahwa analisis ini tidak hanya menfokuskan pada laba yang dicapai, tetapi juga pada investasi yang digunakan untuk menghasilkan laba tersebut.

Semakin besar Return on Investment semakin baik pula perkembangan perusahaan tersebut dalam mengelola aset yang di milikinya dalam menghasilkan laba. Hal ini disebabkan karena Return on Investment tersebut terdiri dari beberapa unsur yaitu penjualan, aset yang digunakan, dan laba atas penjualan yang diperoleh perusahaan. Dengan meningkatnya penjualan maka akan meningkatkan pula laba perusahaan, dengan begitu otomatis Return on Equity perusahaan juga meningkat, dimana Return on Equity merupakan salah satu analisis profitabilitas perusahaan. Pada umumnya semakin tinggi nilai Return on Equity maka semakin baik untuk para pemilik modal.

\section{Tinjauan Pustaka}

\subsection{Analisis Du Pont System}

\section{Pengertian Analisis Du Pont System}

Pada tahun 1919 Du Pont Corporation mempelopori salah satu metode analisa kinerja perusahaan yang sampai dengan saat ini dikenal dengan nama Du Pont Analysis. "Analisa Du Pont System adalah analisa yang mencakup seluruh rasio aktivitas dan margin keuntungan atas penjualan untuk menunjukkan bagaimana rasio ini mempengaruhi profitabilitas". (Weston dan Bringham, 1994).

Return on Asset juga sering disebut Return on Investmentadalah rasio keuntungan setelah pajak terhadap jumlah investasi atau aset. Return on Assetdigunakan untuk mengukur kemampuan dari modal yang diinvestasikan dalam bentuk aset untuk menghasilkan keuntungan bersih (Riyanto, 2001).

Menurut Harahap (1998) Du Pontsystem ini memberikan informasi mengenai berbagai faktor yang menyebabkan naik turunnya kinerja keuangan sebuah perusahaan. Metode hampir sama dengan analisa laporan keuangan biasa, namun pendekatannya lebih integrative dan menggunakan komposisi laporan keuangan sebagai elemen analisisnya. Sistem $d u$ pont adalah sistem yang menggunakan pendekatan tertentu terhadap analisis rasio untuk mengevaluasi efektivitas perusahaan (Horne \& Wachowicz, 2012:182)

Menurut Syafarudin (1993) analisis Du Pont penting bagi manajer untuk mengetahui faktor mana yang paling kuat pengaruhnya antara profit margin dan Total asset turnover terhadap Return on Investment. Analisis du pont systemmerupakan pendekatan untuk 
mengevaluasi profitabilitas dan tingkat pengembalian ekuitas (Keown, Martin, Petty \& Scott, 2011:88).

Tahapan-Tahapan dalam mengukur kinerja keuangan menggunakan Analisis Du Pont System

Tahapan-tahapan dalam melakukan analisis Du Pont Systemadalah sebagai berikut: (Horne \& Wachowicz, 2012:182)

1. Menentukan Total Assets Turnover $=\frac{\text { Penjualan Bersih }}{\text { Total Aset }}$

2. Menentukan Net Profit Margin $=\frac{\text { Laba Bersih setelah pajak }}{\text { Penjualan Bersih }} \times 100$

3. Menentukan Return on Investment

Return on Investment=Net Profit Margin x Total Assets Turnover

4. MenentukanReturn on Equity

Return on Equity = Net Profit Margin x Total Assets $x$ Equity Multiplier

\section{Turnover}

\section{Metode Penelitian}

\subsection{Jenis Penelitian}

Jenis penelitian yang digunakan adalah deskriptif. Penelitian deskriptif adalah penelitian untuk melukiskan secara sistematis fakta-fakta atau karakteristik populasi tertentu baik berupa keadaan, permasalahan, sikap, pendapat, kondisi atau prosedur secara cermat yang tidak untuk mencari maupun menjelaskan hubungan untuk menguji hipotesis (Soewadji, 2012)

\subsection{Populasi dan Sampel}

Populasi dalam penelitian ini adalah Perusahaan TelekomunikasiSeluler yangterdapat di Indonesia, terdiri dari: PT.Smartfren Telecom Tbk,

PT. XL Axiata Tbk,PT.Indosat Tbk, PT.Telekomunikasi Indonesia Tbk,PT Telekomunikasi Selular (Telkomsel), PT.Hutchison 3 Indonesia, PT.Bakrie Telecom Tbk, PT.Sampoerna Telecom, PT.Mobile-8 Telecom, Tbk dan PT.Axis Telecom yang berjumlah 10 perusahaan. Perusahaan yang menjadi sampel dalam penelitian ini dipilih dengan menggunakan teknik pengambilan sampel yaitu Metode purposive sampling. Metode purposive sampling yaitu teknik pengambilan sampel sumber data dengan pertimbangan tertentu/ kriteria tertentu.(Sugiyono, 2009).

Kriteria yang telah ditentukan sebagai berikut:

1. Perusahaan Telekomunikasi Seluler yang tidak melakukan merger 
2. Perusahaan Telekomunikasi Seluler yang terdaftar di Bursa Efek Indonesia (go publik).

3. Perusahaan Telekomunikasi Seluler yang tidak mengalami kebangkrutan (Pailid).

Berdasarkan kriteria yang telah ditetapkan maka terpilih sebanyak 4 perusahaan Telekomunikasi Seluler yang menjadi sampel. Ringkasan prosedur pemilihan sampel dapat dilihat pada tabel 1 sebagai berikut:

Tabel 1

Metode Purposive Sampling

\begin{tabular}{|l|c|l|}
\hline \multicolumn{1}{|c|}{ Keterangan } & Jumlah Perusahaan & \multicolumn{1}{|c|}{ Penjelasan } \\
\hline $\begin{array}{l}\text { Populasi perusahaan } \\
\text { Telekomunikasi Seluler }\end{array}$ & 10 & - \\
\hline Perusahaan yang merger & $(3)$ & $\begin{array}{l}\text { PT.Mobile-8 Telecom,Tbk, } \\
\text { PT.Sampoerna Telecom, dan } \\
\text { PT.Axis Telecom }\end{array}$ \\
\hline Perusahaan yang bangkrut & $(1)$ & PT.Bakrie Telecom, Tbk. \\
\hline Perusahaan yang tidak go publik & $(2)$ & $\begin{array}{l}\text { PT.Telekomunikasi Selular } \\
\text { (Telkomsel) dan PT.Hutchison 3 } \\
\text { Indonesia }\end{array}$ \\
\hline $\begin{array}{l}\text { Perusahaan yang terpilih } \\
\text { menjadi sampel }\end{array}$ & 4 & $\begin{array}{l}\text { PT.Smartfren Telecom, Tbk } \\
\text { PT.XL.Axiata,Tbk, } \\
\text { PT.Indosat,Tbk, dan } \\
\text { PT.Telekomunikasi Indonesia,Tbk }\end{array}$ \\
\hline
\end{tabular}

Sumber: data diolah, 2016

Dari kriteria tersebut maka terpilih 4 perusahaan yang menjadi sampel yaitu perusahaan yang terdaftar di Bursa Efek Indonesia (go publik) terdiri dari PT.Smartfren Telecom, Tbk, PT.XL.Axiata, Tbk, PT.Indosat, Tbk dan PT.Telekomunikasi Indonesia, Tbk.

\subsection{Jenis dan Sumber Data}

\section{Jenis data}

Penelitian ini menggunakan data sekunder, yaitu data yang tidak langsung memberikan data kepada peneliti, misalnya penelitian harus melalui orang lain atau mencari melalui dokumen (Sugiyono, 2005). Data sekunder umumnya berupa catatan atau laporan keuangan yang tersusun dalam arsip (data dokumenter) yang dipublikasikan oleh Bursa Efek Indonesia.

\section{Sumber Data}

Sumber data dalam penelitian ini berupa data laporan keuangan yang dipublikasikan di Bursa Efek Indonesia selama periode 2012-2014 diperoleh dari website IDX yaitu www.idx.co.id. Ada pun data yang dibutuhkan yaitu berupa laporan keuangan:

a. Laporan Posisi Keuangan per 31 Desember 2012-2014

b. Laporan Laba Rugi untuk tahun berakhir 2012-2014 


\subsection{Metode Pengumpulan Data}

Metode pengumpulan data yang digunakan dalam penelitian ini yaitu metode dokumentasi atau studi kepustakaan yaitu penelitian yang dilakukan dengan cara mengumpulkan, mengklasifikasi, dan menganalisis data tertulis yang diperoleh dari catatan yang terpublikasikan, buku teks, surat-surat dan artikel (Noor, 2014).

\subsection{Definisi Operasional}

Definisi operasional adalah penentuan konstrak atau sifat yang akan dipelajari sehingga menjadi variabel yang dapat diukur (Sugiyono, 2012).

Definisi operasional yang digunakan dalam penelitian:

1. Total Assets Turnover

Total Assets Turnover mengukur perputaran dari semua aset yang dimiliki perusahaan dan menunjukkan efektivitas penggunaan seluruh aset perusahaan dalam rangka menghasilkan penjualan.

2. Net Profit Margin

Net Profit Margin digunakan mengukur tingkat keuntungan yang dapat dicapai oleh perusahaan dihubungkan dengan penjualannya.Keuntungan penjualan setelah menghitung seluruh biaya dan pajak penghasilan.

3. Return on Investment

Return on Investmentdigunakan untuk mengukur kemampuan perusahaan dengan keseluruhan dana yang ditanamkan dalam aset yang digunakan untuk operasinya perusahaan untuk menghasilkan keuntungan.

\section{Return on Equity}

Return on Equitydigunakan untuk mengukur besarnya tingkat pendapatan yang tersedia bagi para pemilik perusahaan (baik pemegang saham biasa maupun pemegang saham preferen) atas modal yang mereka investasikan di dalam perusahaan.

\subsection{Teknik Analisis Data}

Analisis data adalah proses mencari dan menyusun yang secara sistematis data yang diperoleh dari hasil wawancara, catatan lapangan, dan dokumentasi (Sugiyono, 2009). Dalam penelitian ini teknik analisis yang digunakan adalah analisis deskriptif kualitatif yaitu dengan memberikan ulasan atau interpretasi terhadap data yang diperoleh sehingga menjadi lebih jelas dan bermakna dibandingkan dengan sekedar angka-angka. Dalam penelitian ini, teknik analisis yang digunakan sebagai berikut:

1. Total Assets Turnover $=\frac{\text { Penjualan Bersih }}{\text { Total Aset }} \mathrm{x}$ kali 
2. Net Profit Margin $=\frac{\text { Laba Bersih Setelah Pajak }}{\text { Penjualan Bersih }} \times 100$

3. Return on Investment $=$ Net Profit Margin $x$ Total Assets Turnover

4. Return on Equity= Net Profit Margin x Total Assets x Equity Multiplier

\section{Turnover}

\section{Hasil Penelitian dan Pembahasan}

4.1. Analisis Kinerja Keuangan Perusahaan

Berikut ini adalah Analisis Du Pont System:

\section{Tabel 2}

Analisis Kinerja Keuangan pada PT.Smartfren Telecom, Tbk Periode 2012-2014

\begin{tabular}{|l|c|c|c|}
\hline \multicolumn{1}{|c|}{ Variabel } & Tahun 2012 & Tahun 2013 & $\begin{array}{c}\text { Tahun } \\
2014\end{array}$ \\
\hline Total Assets Turnover & $0,12 \mathrm{kali}$ & $0,15 \mathrm{kali}$ & $0,17 \mathrm{kali}$ \\
\hline Net Profit Margin & $-94,78 \%$ & $-104,35 \%$ & $-46,68 \%$ \\
\hline Return on investment & $-11,37 \%$ & $-15,65 \%$ & $-7,94 \%$ \\
\hline Return on equity & $-32,75 \%$ & $-81,38 \%$ & $-35,48 \%$ \\
\hline
\end{tabular}

Sumber: data diolah, 2016

Berdasarkan tabel diatas, dapat disimpulkan bahwa kinerja keuangan pada PT.Smartfren Telecom, Tbk mengalami kondisi buruk. Hal tersebut bisa dilihat dari Total Assets Turnover yang mengalami peningkatan setiap tahun akan tetapi dibawah standar industri. Lalu Net Profit Marginpada PT.Smartfen Telecom, Tbk mengalami fluktuasi, hal tersebut karena pada tahun 2012 dan 2013 mengalami peningkatan jumlah beban usaha, dan mengalami penurunan jumlah beban usaha pada tahun 2014. Lalu Return on Investment pada PT.Smartfren Telecom, Tbk mengalami fluktuasi. Hal tersebut dikarenakan 2 faktor yang mempengaruhi yaitu Total Assets Turnover dan Net profit margin. Lalu Return on Equity pada PT.Smartfren Telecom, Tbk mengalami fluktuasi juga. Hal tersebut dikarenakan 2 faktor yang mempengaruhi yaitu Return on Investment dan Equity Multiplier. Berikut ini adalah Analisis Du Pont System:

Tabel 3

Analisis Kinerja Keuangan pada PT.XL Axiata, Tbk Periode 2012-2014

\begin{tabular}{|l|c|c|c|}
\hline Variabel & Tahun 2012 & Tahun 2013 & $\begin{array}{c}\text { Tahun } \\
2014\end{array}$ \\
\hline Total Assets Turnover & $0,59 \mathrm{kali}$ & $0,53 \mathrm{kali}$ & $0,37 \mathrm{kali}$ \\
\hline Net Profit Margin & $13,09 \%$ & $4,97 \%$ & $-3,91 \%$ \\
\hline Return on investment & $7,72 \%$ & $2,63 \%$ & $-1,45 \%$ \\
\hline Return on equity & $17,83 \%$ & $6,92 \%$ & $-6,61 \%$ \\
\hline
\end{tabular}

Sumber: data diolah, 2016

Berdasarkan tabel diatas, dapat disimpulkan bahwa kinerja keuangan pada PT.XL Axiata, Tbk mengalami kondisi buruk. Hal tersebut bisa dilihat dari Total Assets Turnover yang mengalami penurunan dan bahkan dibawah standar industri. Lalu Net Profit 
Marginpada PT.XL Axiata, Tbk mengalami penurunan, hal tersebut dikarenakan semakin meningkatnya jumlah beban usaha. Lalu Return on Investment pada PT.Smartfren Telecom, Tbk mengalami penurunan. Hal tersebut dikarenakan 2 faktor yang mempengaruhi yaitu Total Assets Turnover dan Net profit margin. Lalu Return on Equity pada PT.Smartfren Telecom, Tbk mengalami penurunan juga. Hal tersebut dikarenakan 2 faktor yang mempengaruhi yaitu Return on Investment dan Equity Multiplier.

Berikut ini adalah Analisis Du Pont System:

\section{Tabel 4}

Analisis Kinerja Keuangan pada PT.Indosat, Tbk Periode 2012-2014

\begin{tabular}{|l|c|c|c|}
\hline Variabel & Tahun 2012 & Tahun 2013 & $\begin{array}{c}\text { Tahun } \\
2014\end{array}$ \\
\hline Total Assets Turnover & $0,41 \mathrm{kali}$ & $0,44 \mathrm{kali}$ & $0,45 \mathrm{kali}$ \\
\hline Net Profit Margin & $3,91 \%$ & $-11,08 \%$ & $-7,73 \%$ \\
\hline Return on investment & $1,60 \%$ & $-4,88 \%$ & $-3,48 \%$ \\
\hline Return on equity & $4,56 \%$ & $-16,10 \%$ & $-13,05 \%$ \\
\hline
\end{tabular}

Sumber: data diolah, 2016

Berdasarkan tabel diatas, dapat disimpulkan bahwa kinerja keuangan pada PT.XL Axiata, Tbk mengalami kondisi buruk. Hal tersebut bisa dilihat dari Total Assets Turnover yang mengalami peningkatan akan tetapi dibawah standar industri. Lalu Net Profit Margin pada PT.XL Axiata, Tbk mengalami fluktuasi, hal tersebut dikarenakan semakin meningkatnya jumlah beban usaha dan jumlah beban lain-lain pada tahun 2013 dan mengalami penurunan jumlah beban usaha dan jumlah beban lain-lain pada tahun 2014. Lalu Return on Investment pada PT.Smartfren Telecom, Tbk mengalami fluktuasi. Hal tersebut dikarenakan 2 faktor yang mempengaruhi yaitu Total Assets Turnover dan Net profit margin. Lalu Return on Equity pada PT.Smartfren Telecom, Tbk mengalami fluktuasi juga. Hal tersebut dikarenakan 2 faktor yang mempengaruhi yaitu Return on Investment dan Equity Multiplier. Berikut ini adalah Analisis Du Pont System:

\section{Tabel 5}

Analisis Kinerja Keuangan pada PT.Telekomunikasi Indonesia, Tbk Periode 2012-2014

\begin{tabular}{|l|c|c|c|}
\hline Variabel & Tahun 2012 & Tahun 2013 & Tahun 2014 \\
\hline Total Assets Turnover & $0,69 \mathrm{kali}$ & $0,65 \mathrm{kali}$ & $0,64 \mathrm{kali}$ \\
\hline Net Profit Margin & $23,84 \%$ & $24,60 \%$ & $23,94 \%$ \\
\hline Return on investment & $16,45 \%$ & $16,00 \%$ & $15,32 \%$ \\
\hline Return on equity & $27,31 \%$ & $26,40 \%$ & $25,12 \%$ \\
\hline
\end{tabular}

Sumber: data diolah, 2016

Berdasarkan tabel diatas, dapat disimpulkan bahwa kinerja keuangan pada PT.Telekomunikasi Indonesia, Tbk mengalami kondisi yang cukup baik. Hal tersebut bisa 
dilihat dari Total Assets Turnover yang mengalami penurunan dan bahkan dibawah standar industri. Lalu Net Profit Margin pada PT Telekomunikasi Indonesia, Tbk mengalami fluktuasi, hal tersebut dikarenakan pada tahun 2013 mengalami peningkatan akan tetapi pada tahun 2014 mengalami penurunan, dikarenakan pendapatan usaha meningkat dibandingkan tahun sebelumnya akan tetapi tidak diikuti dengan peningkatan yang signifikan terhadap laba bersih setelah pajak. Lalu Return on Investment pada PT.Telekomunikasi Indonesia, Tbk mengalami penurunan. Hal tersebut dikarenakan 2 faktor yang mempengaruhi yaitu Total Assets Turnover dan Net profit margin. Lalu Return on Equity pada PT.Telekomunikasi Indonesia,Tbk mengalami penurunan juga. Hal tersebut dikarenakan 2 faktor yang mempengaruhi yaitu Return on Investment dan Equity Multiplier.

\subsection{Perbandingan Kinerja Keuangan Perusahaan}

Tabel 6

Perbandingan Kinerja Keuangan pada PT.Telekomunikasi, Tbk Periode 2012-2014

\begin{tabular}{|c|c|c|c|c|c|c|}
\hline \multirow{2}{*}{ Perusahaan } & \multirow{2}{*}{ Variabel } & \multicolumn{3}{|c|}{ Tahun } & \multirow{2}{*}{$\begin{array}{l}\text { Standar } \\
\text { Industri }\end{array}$} & \multirow{2}{*}{ Kondisi } \\
\hline & & 2012 & 2013 & 2014 & & \\
\hline \multirow{4}{*}{$\begin{array}{l}\text { PT.Smartfren } \\
\text { Telecom, Tbk }\end{array}$} & $\begin{array}{l}\text { Total Assets } \\
\text { Turnover }\end{array}$ & 0,12 kali & 0,15 kali & 0,17 kali & 2 kali & Buruk \\
\hline & Net Profit Margin & $-94,78 \%$ & $-104,35 \%$ & $-46,68 \%$ & $20 \%$ & Buruk \\
\hline & $\begin{array}{l}\text { Return on } \\
\text { Investment }\end{array}$ & $-11,37 \%$ & $-15,65 \%$ & $-7,94 \%$ & $30 \%$ & Buruk \\
\hline & Return on Equity & $-32,75 \%$ & $-81,38 \%$ & $-35,48 \%$ & $40 \%$ & Buruk \\
\hline \multirow{4}{*}{ PT.XL.Axiata, Tbk } & $\begin{array}{l}\text { Total Assets } \\
\text { Turnover }\end{array}$ & 0,59 kali & 0,53 kali & 0,37 kali & 2 kali & Buruk \\
\hline & Net Profit Margin & $13,09 \%$ & $4,97 \%$ & $-3,91 \%$ & $20 \%$ & Buruk \\
\hline & $\begin{array}{l}\text { Return on } \\
\text { Investment }\end{array}$ & $7,72 \%$ & $2,63 \%$ & $-1,45 \%$ & $30 \%$ & Buruk \\
\hline & Return on Equity & $17,83 \%$ & $6,92 \%$ & $-6,61 \%$ & $40 \%$ & Buruk \\
\hline \multirow{4}{*}{ PT. Indosat, Tbk } & $\begin{array}{l}\text { Total Assets } \\
\text { Turnover }\end{array}$ & 0,41 kali & 0,44 kali & 0,45 kali & 2 kali & Buruk \\
\hline & Net Profit Margin & $3,91 \%$ & $-11,08 \%$ & $-7,73 \%$ & $20 \%$ & Buruk \\
\hline & $\begin{array}{l}\text { Return on } \\
\text { Investment }\end{array}$ & $1,60 \%$ & $-4,88 \%$ & $-3,48 \%$ & $30 \%$ & Buruk \\
\hline & Return on Equity & $4,56 \%$ & $-16,10 \%$ & $-13,05 \%$ & $40 \%$ & Buruk \\
\hline \multirow{4}{*}{$\begin{array}{l}\text { PT.Telekomunikasi } \\
\text { Indonesia, Tbk }\end{array}$} & $\begin{array}{l}\text { Total Assets } \\
\text { Turnover }\end{array}$ & 0,69 kali & 0,65 kali & 0,64 kali & 2 kali & $\begin{array}{l}\text { Cukup } \\
\text { Baik }\end{array}$ \\
\hline & Net Profit Margin & $23,84 \%$ & $24,60 \%$ & $23,94 \%$ & $20 \%$ & Baik \\
\hline & $\begin{array}{l}\text { Return on } \\
\text { Investment }\end{array}$ & $16,45 \%$ & $16,00 \%$ & $15,32 \%$ & $30 \%$ & $\begin{array}{l}\text { Cukup } \\
\text { Baik }\end{array}$ \\
\hline & Return on Equity & $27,31 \%$ & $26,40 \%$ & $25,12 \%$ & $40 \%$ & $\begin{array}{c}\text { Cukup } \\
\text { Baik }\end{array}$ \\
\hline
\end{tabular}

Sumber: Kasmir, 2014 
Berdasarkan perhitungan diatas dengan menggunakan analisis $d u$ pont system, bahwa kondisi kinerja keuangan Perusahaan Telekomunikasi, Tbk periode 2012-2014 yaitu kondisi kinerjanya sebagian besar buruk karna dibawah standar industri, kecuali kinerja keuangan perusahaan PT.Telekomunikasi Indonesia, Tbk cukup baik walaupun dibawah standar industri.

\section{Kesimpulan dan Saran}

\subsection{Kesimpulan}

Berdasarkan analisis dan pembahasan yang telah dibahas, maka dapat disimpulkan sebagai berikut:

1. Dari perhitungan dengan menggunakan analisis $D u$ Pont System pada Perusahaan Telekomunikasi, Tbk yang terdaftar di Bursa Efek Indonesia periode 2012-2014 dapat disimpulkan bahwa kinerja Perusahaan Telekomunikasi, Tbk yang terdaftar di Bursa Efek Indonesia pada umumnya kurang baik karena nilai Return on Investment dan Return on equity negatif dan bahkan berada dibawah standar industri.

2. Dari perhitungan dengan menggunakan analisis Du Pont System, hanya PT.Telekomunikasi Indonesia, Tbk yang kinerja keuangannya cukup baik karena nilai Return on Investment dan Return on equity positif walaupun berada dibawah standar industri.

\subsection{Saran}

Berdasarkan kesimpulan diatas, maka di sarankan untuk masing-masing Perusahaan

Telekomunikasi, Tbk yang terdaftar di Bursa Efek Indonesia sebagai berikut:

1. Agar masing-masing Perusahaan Telekomunikasi, Tbk untuk meningkatkan kinerja keuangan perusahaan yaitu meningkatkan nilai Return on Investment, dengan cara melakukan efisiensi terhadap biaya dan meningkatkan perputaran total aset yaitu dengan cara menyeimbangkan total aset dan meningkatkan penjualan, agar peningkatan penjualan sebanding dengan peningkatan total aset.

2. Agar masing-masing Perusahaan Telekomunikasi, Tbk untuk meningkatkan Return on equity dengan memperkecil equity multiplier, berarti kinerjanya akan semakin baik karena persentase untuk pembayaran bunga semakin kecil. Jadi perusahaan perlu meningkatkan sumber pendanaan internal dibandingkan sumber pendanaan eksternal. 
Daftar Pustaka

Alwi, Syafaruddin.1993. Alat-alat Analisis Dalam Pembelanjaan. Edisi Keempat, Andi Offset. Yogyakarta.

Anugrahani, Evida. 2007. Analisis Du Pont System Dalam Mengukur Kinerja

Keuangan Perusahaan (Studi Kasus Pada PT. Aqua Golden missisipi Tbk, PT. Mayora Indah Tbk, PT. Ultra Jaya Milk Tbk).

Fahmi, Irham. 2011. Analisis Kinerja Keuangan. Bandung: Alfabet.

Freddy dan Hildawati. 2014. Analisis Kinerja Keuangan Perusahaan Dengan Menggunakan Metode Du Pont SystemStudi kasus Pada Perusahaan Food And Beverage Yang Terdaftar Di BEI Periode Tahun 2008-2010. Forum Ilmiah. Volume 11 Nomor 2.Mei 2014

Hanafi, Mamduh M. \& Abdul Halim. 2009. Analisis Laporan Keuangan. Edisi keempat. Cetakan pertama. Yogyakarta: UPP STIM YKPN.

Harahap, Sofyan Syafri. 1998. Analisis Kritis Atas Laporan Keuangan. Jakarta: PT. Raja Grafindo Persada.

Harahap, Sofyan Syafri. 2004. Analisis Kritis Atas Laporan Keuangan. Jakarta:PT. Raja Grafindo Persada.

Horne, Van James C dan John M. Wachowicz,Jr. 2012. Prinsip-prinsip Manajemen Keuangan. Edisi 13 Buku 1. Jakarta: Salemba Empat.

Ikatan Akuntan Indonesia. 2002. Standar Akuntansi Keuangan. Jakarta: Salemba Empat.

Ikatan Akuntansi Indonesia dalam Pernyataan Standar Akuntansi Keuangan No.1 Revisi 2009. Laporan Keuangan.

Ikatan Akuntansi Indonesia dalam Pernyataan Standar Akuntansi Keuangan No.1 Revisi 2013 Komponen Laporan Keuangan.

Jumingan. 2006. Analisis Laporan Keuangan. Jakarta: PT. Bumi Aksara.

Kasmir. 2010. Pengantar Manajemen Keuangan. Edisi kesatu. Jakarta: Kencana Prenad Media Group.keenam. Jakarta: PT.Indeks.

Kasmir.2014. Analisis Laporan Keuangan. Cetakan ketujuh. Jakarta: PT.Raja Grafindo Persada.

Keown, Arthur J. dan John D. Martin, J.William Petty, dan David F.Scott, Jr. 2011. Manajemen Keuangan: Prinsip dan Penerapan. Edisi Kesepuluh Jilid 1. Jakarta: PT Indeks.

Lianto, David. 2013. Penilaian Kinerja Keuangan Perusahaan Menggunakan Analisis Du Pont Pada Perusahaan Rokok Yang Terdaftar Di BEI 
Periode Tahun 2008-2010.Jurnal JIBEKA. Volume 7. No.2. Agustus $2013: 25-31$.

Martono dan Agus Harjito. 2005. Manajemen Keuangan. Yogyakarta: Ekonisia.

Munawir, S. 1979. Analisis Laporan Keuangan. Edisi keempat. Yogyakarta: Liberty.

Nikmah, Evi Ziadatul, Muhammad Saifi dan Achmad Husaini. 2014. Analisis Rasio Keuangan Dalam Du Pont System Sebagai Dasar Untuk Mengukur Kinerja Keuangan Perusahaan (Studi Kasus pada PT. Nippon Indosari Corpindo, Tbk yang Terdaftar Pada BEI Periode 2010 - 2012).

Noor, Juliansyah.2014. Analisis Data Penelitian Ekonomi \& Manajemen. Jakarta: PT Gramedia Widia Sarana Indonesia.

Orminston, Ailen \& Lyin M.Fraser. 2004. Memahami Laporan Keuangan. Edisi keenam. Jakarta: PT.Indeks.

Prina A, Ryandra, Sri Mangesti Rahayu dan Topowijono. 2014. Analisis kinerja keuangan perusahaan dengan menggunakan Metode Du Pont System studikasus pada ud. Az zahra food periode tahun 2011-2013. Jurnal Administrasi Bisnis (JAB)

Vol. 16 No. 1.1 November 2014

Raharjo, Budi. 2001. Laporan Keuangan Perusahaan. Cetakan pertama. Yogyakarta: Gajah Mada University Press.

Rivai, Fawzi. 2005. Perfomance Appraisal. Jakarta: RT Grafindo Persada,

Riyanto, Bambang. 1998. Dasar-dasar Pembelanjaan Perusahaan. Yogyakarta: Gajah Mada.

Riyanto, Bambang. 2001. Dasar-dasar Pembelanjaan Perusahaan. Yogyakarta: Gajah Mada.

Sudana. 2011. Manajemen Keuangan Perusahaan Teori Dan Praktik. Erlangga. PT Gelora Aksara Pratama.

Suhardi, Sigit. 2001. Pengantar Metodologi Penelitian Sosial- BisnisManajemen. Yogyakarta: FE UST.

Sugiyono,2005. Memahami Penelitian Kualitatif. Bandung: Alfabeta.

Sugiyono, 2009. Metode Penelitian Kuantitatif Kualitatif dan $R \& D$.

Bandung: Alfabeta

Sugiyono, 2012. Metode Penelitian Kuantitatif Kualitatif dan $R \& D$.

Bandung: Alfabeta

Soewadji, Jusuf.2012. Pengantar Metodologi Penelitian. Jakarta: Mitra 
Wacana Media.

Weston. J.F., E.F.Brigham. 2004. Dasar-dasar Manajemen Keuangan I dan II Edisi 10. Jakarta: Erlangga

www.bakrietelecom.com/index.html

www.bambangpurnomohp.blogspot.co.id/2012/08/ceria-tenggelam-esia-berharapbersinar.html

www.bisnis.tempo.co/read/news/2015/03/16/092650234/utang-menumpuk-bakrie-telecomterancam-tinggal-papan-nama

www.//id.wikipedia.org/wiki/Telekomunikasi_seluler_di_Indonesia

www.//id.wikipedia.org/wiki/Bakrie_Telecom

www.idx.co.id

www.indosatooredoo.com/id/personal

www.indosat.com

www.harianti.com./naas-empat-dari-lima-layanan-CDMA-Indonesia-pilih-akhiri-riwayathidupnya/

www.smartfren.com/id/

www.sampoernatelecom.com/

www.telkom.co.id/

www.telkomsel.com/

www.xl.co.id/

www.xl.co.id/axis/id/home 